\title{
It does matter which side of the labour market is taxed
}

Citation for published version (APA):

Muysken, J., \& van Veen, A. P. (1996). It does matter which side of the labour market is taxed. METEOR, Maastricht University School of Business and Economics. METEOR Research Memorandum No. 021 https://doi.org/10.26481/umamet.1996021

Document status and date:

Published: 01/01/1996

DOI:

10.26481/umamet.1996021

Document Version:

Publisher's PDF, also known as Version of record

\section{Please check the document version of this publication:}

- A submitted manuscript is the version of the article upon submission and before peer-review. There can be important differences between the submitted version and the official published version of record.

People interested in the research are advised to contact the author for the final version of the publication, or visit the DOI to the publisher's website.

- The final author version and the galley proof are versions of the publication after peer review.

- The final published version features the final layout of the paper including the volume, issue and page numbers.

Link to publication

\footnotetext{
General rights rights.

- You may freely distribute the URL identifying the publication in the public portal. please follow below link for the End User Agreement:

www.umlib.nl/taverne-license

Take down policy

If you believe that this document breaches copyright please contact us at:

repository@maastrichtuniversity.nl

providing details and we will investigate your claim.
}

Copyright and moral rights for the publications made accessible in the public portal are retained by the authors and/or other copyright owners and it is a condition of accessing publications that users recognise and abide by the legal requirements associated with these

- Users may download and print one copy of any publication from the public portal for the purpose of private study or research.

- You may not further distribute the material or use it for any profit-making activity or commercial gain

If the publication is distributed under the terms of Article $25 \mathrm{fa}$ of the Dutch Copyright Act, indicated by the "Taverne" license above, 


\title{
It does matter which side of the labour market is taxed"
}

\author{
J. Muysken \\ A.P. van Veen \\ University of Limburg \\ Faculty of Economics \\ P.O. Box 616 \\ 6200 MD Maastricht \\ The Netherlands \\ Tel. +31433883821 \\ Fax +31433261555
}

E-mail: J.Muysken@algec.RuLimburg.NL

E-mail: T.vanVeen@algec.RuLimburg.NL

Paper presented at the AEA-Conference in Göteborg, Sweden, 9-11 May 1996

\begin{abstract}
In this paper we discuss the influence of tax shifting on wages and employment. The paper is related to earlier research in this field, both for the Netherlands and for other European welfare states. Our approach differs since we pay explicit attention to the well-known theoretical result that it does not matter which side of the market is taxed (Dalton's Law). We will analyse the mechanisms behind tax shifting. Further we want to analyse whether a shift from employers' to employees' burden has an influence on wages and employment.

The paper discusses the influence of taxes on wages and employment in various bargaining settings: the perfect competition model, right-to-manage models (including that of bilateral monopoly) and efficiency wage models are analysed. We conclude that the results depend on the framework that is used in the description of wage setting behaviour. The theorem that it is irrelevant which side of the market is taxed, does not hold for right-to-manage and efficiency wage models.

In estimations for the Netherlands, the elasticity of wage costs with respect to employers' taxes is usually found to lie around 0.9 , whereas the elasticity with respect to employees' taxes usually is found to lie around 0.4. This apparent violation of Dalton's Law has never been explained before. However, it can be explained from our analysis. Moreover, we show the importance of this result for the impact of a recent tax reform in the Netherlands on wages.
\end{abstract}

3rd June 1996

We would like to thank Lex Borghans for his stimulating comments on an earlier version of this paper. Further we are grateful to Egbert Jongen for his computational assistance. We thank the Netherlands Association of Science (NWO) for their financial support to this research. 


\section{Introduction}

The aim of this paper is to analyse tax shifting, and more in particular to investigate whether the legal distribution of taxes on wages between employers and employees matters in measuring the economic burden of a tax: does it matter which side of the labour market is taxed? According to Dalton's law this does not matter: the economic burden of a tax is independent of the legal burden that is imposed on both parties (Dalton, 1936; Keller, 1980).

This result follows from simple demand and supply analysis, where prices clear the market and a new equilibrium is restored after the distortion caused by a (change in the) tax. However, the situation on the labour market differs from such a type of market. The wage setting process is in most countries characterized by a bargaining process where wage contracts are concluded. The terms of the various contracts vary, but are fixed for at least one year. Thus prices on the labour market do not adjust in line with the model that underlies the work of Dalton. ${ }^{1}$ Moreover, in contrast to the situation on the goods market, the legal distribution of the various taxes and contributions for social security is heavily discussed in actual life. Following Dalton's law, one could ask why such a discussion is useful.

In this context, Blinder (1988) has stated the problem clearly:

'(..) consider what may be the most basic theorem of public finance: the irrelevance of the side of the market on which a tax is levied. We all have had fun explaining to our beginning students why it doesn't matter whether the payroll tax is levied on employers or employees. Then why (..) do Congress, labor and management all think the decision so momentous? Sheer lack of understanding? (..). I submit that part of the answer is (..) that we economists insist on thinking long-run equilibrium while everyone else lives in short-run disequilibrium. The truth of the matter is that the incidence of the payroll tax may differ dramatically in the short and long runs.' (p. 12).

Blinder points to the fact that, if prices are sticky, the economic burden equals the legal burden and therefore tax-shifting is not possible. Consequently, it matters on which side of the market the tax is levied. However, one can argue that this is only a short-run problem: in the long run, whenever it is reached, it still does not matter on which side of the market the tax is levied. Blinder's answer is based on wages that are determined on a competitive labour market. However, in Western economies wages are set in bargaining processes between employers and employees. Does that change the conclusions of the market model?

In this contribution, we want to extend the answer that has been given by Blinder. We will discuss the effects of taxation in models of wage determination that differ from the market model. The aim is to analyse whether the legal distribution of taxes does matter and consequently the related discussions do make sense. For that purpose we will compare various models with respect to the effects of taxes on wages: a model of perfect competition, right-to-manage models, including that of bilateral monopoly and efficiency wage models.

The chapter is organized as follows. In the next section we start with a theoretical analysis of the tax shifting problem and introduce Dalton's law. We apply our findings to the various models mentioned above in section 3. In section 4 we present the development of the wedge in the Netherlands during the period

It needs to be said that Dalton's law is one of the key concepts of modern public finance regarding tax shifting. See for example Musgrave and Musgrave (1987) and Stiglitz (1988). 
1960-1993, both at the aggregate level and at the level of an individual employee. Next, in section 5 we review empirical research with respect to tax shifting in the Netherlands and present some own estimation results. The final section provides the conclusions.

\section{Tax incidence and Dalton's Law}

\subsection{Tax burden: concept and definition}

In dealing with the effects of taxation we have to make a distinction between the legal liability for payment or legal burden (statutory incidence) and the actual economic burden (economic incidence) of a tax for economic agents. If the final or economic incidence differs from the statutory incidence, taxes have been shifted. $^{2}$

When we apply the analysis to the labour market, we should realize that taxes are levied on both sides of that market. Income taxes and employees' contributions for social security are taxes that are levied on the supply side of the labour market, while payroll taxes or employers' contributions for social security are levied on the demand side of the market. Further, if taxes are levied on a market, a distinction must be made between (1) the before-tax or transaction price on that market, i.e. gross wage, (2) the after-tax sellers price, i.e. net wage, and (3) the after-tax buyers price, i.e. wage costs. The tax causes a difference between the seller's and the buyers' net price or, the tax causes a wedge between these prices.

In order to define our concepts more precisely, we use the following framework. Let the gross wage be equal to $W$. Then the wage costs paid by employers, $W C$ will include payroll taxes and employers' contributions for social security with a share (+ - 1) of gross wages; hence $W C=+. W$. And the net wages received by employees, $W N$ will be net of income taxes and employees' contributions for social security, with a share of $(1-))$ of gross wages; hence $W N=)$. $W$. One can also look at the wedge, which can be defined as the ratio between wage costs and net wages: this is equal to $+/) .{ }^{3}$ Finally, in order to introduce the last concept, let the equilibrium wage in absence of taxes be $W^{*}{ }^{4}$ Related to the gross wage we then have $W^{*}$ $=\ni . W$, with $\ni=1$ at the start of the analysis.

2 For example, sales taxes are levied on the seller of a good. However, if the seller can increase his price by exactly the amount of the tax, without any drop in sales, the tax is actually paid by the buyer of the good. Then the statutory incidence is on the seller of the good while the economic incidence falls on the buyer of this good.

3 This definition is chosen for analytical reasons. In section 4 we will also use the more standard definition of +- ).

4 For simplicity reasons, we assume that the starting point of the analysis is a situation where no taxes are levied. 
For analytical purposes and following the practice in empirical research, we will present our analysis in logarithms. These will be expressed as lower case variables. ${ }^{5}$ Then we have now defined, given the equilibrium wage in the absence of taxes $\mathrm{w}^{*}$,:

$\begin{array}{lll}\text { gross wage } & w \ni w(\&) & \\ \text { wage costs } & w c \ni \%, & , \exists 0 \\ \text { net wage } & w n \ni w \% * & * \# 0\end{array}$

In order to look at the division of the wedge according to the statutory burden, one simply has to look at the statutory tax rates. Tax shifting takes place when the division of the wedge according to the economic burden is different. This can be illustrated in Figure 1, which for analytical reasons assumes log-linear supply and demand curves of labour in absence of taxes, $n^{s}$ and $n^{d}$, respectively. Point $\mathrm{A}$ is the equilibrium without taxes. The equilibrium wage then is equal to $w^{*}$. Introduction of employees' taxes shifts the supply curve to the left, to $n^{s \prime}$. And when employers' taxes and contributions are introduced, the labour demand curve also shifts to the left, to $n^{d \prime}$. This has a decreasing impact on the gross wage. The new equilibrium level is represented by point $\mathrm{E}$.

Figure $1 \quad$ Taxes and the labour market

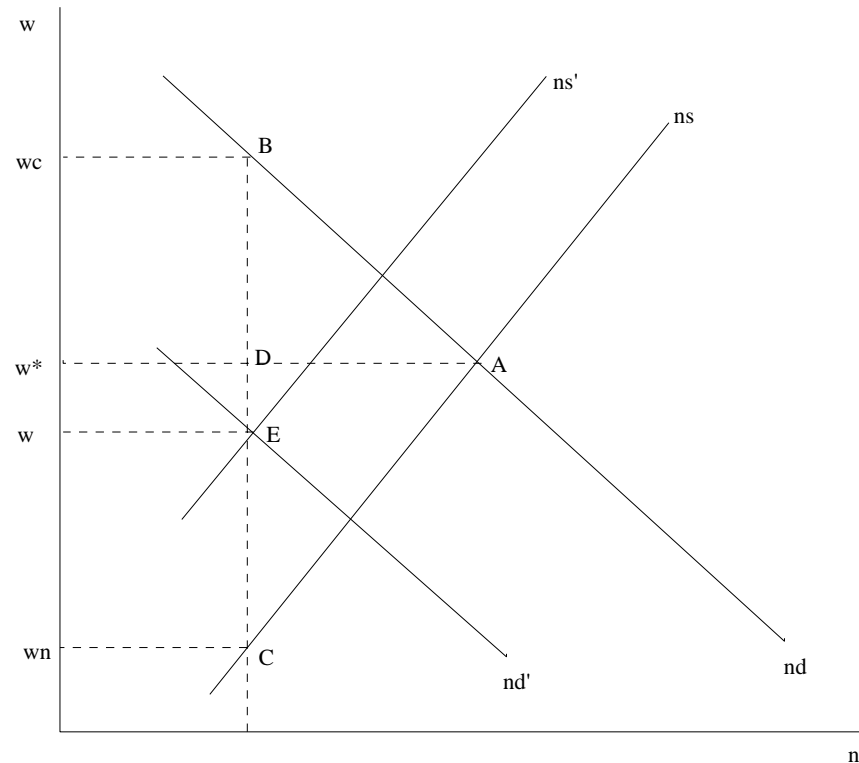

From Figure 1 one can easily see that in logarithms the statutory incidence for employers, BE, is equal to $w c-w=$, and that for employees, EC, equals $w-w n=-*$. Together they constitute the total wedge, $\mathrm{BC}$,

In the case of Greek symbols we have, $=\ln +, *=\ln )$ and $(=\ln \ni$. 
or, - *. The distribution of the economic incidence differs because the transaction price (gross wages) has decreased. This decreases the employers' burden and increases the employees' burden (cf. note 2). Hence, to measure the economic incidence, we correct the statutory burden with the change in the transaction price. It will be clear from Figure 1 that after the introduction of the taxes, the transaction price has decreased with DE, from $w^{*}$ to $w$. Hence, we can derive that the economic burden for the employers, BD, equals $(w c-w)-\left(w^{*}-w\right)=,-\left(\right.$ The economic burden for employees, DC, then is $(w-w n)+\left(w^{*}-w\right)=$ $(-*$. In this context one should realize that the core of the concept of economic burden is the change in the transaction price that occurs after the imposition of the tax. If the transaction price does not change, the economic burden is equal to the statutory burden. Consequently, in the measurement of the economic burden, one has to take into account this change in the transaction price.

Both ways of dividing the total burden are summarized in Table 1. It is clear that the decomposition of the wedge according to the statutory burden is different from that according to the economic burden when ( is not equal to zero, i.e. when the gross wage differs from the equilibrium wage. When ( is positive, as is the case in Figure 1, employers have succeeded in shifting part of their burden towards the employees. We will call this backward shifting, since in this case the demand side of the market dominates. In the opposite case the supply side will dominate and forward shifting takes place: then (is negative. Thus ( is a parameter which indicates whether shifting takes place and in which direction.

Table 1 Tax burden and distribution of tax change

\begin{tabular}{|c|c|c|}
\hline & Statutory & Economic $\left(\mathrm{w}^{*}-\mathrm{w}=()\right.$ \\
\hline Employers & $w c \& w \ni$ & $w c \& w(\ni, \&($ \\
\hline Employees & $w \& w n \ni \&$ & $w(\& w n \ni(\& *$ \\
\hline Total & $w c \& w n \ni, \& *$ & $w c \& w n \ni, \& *$ \\
\hline $\begin{array}{l}\text { Distribution } \\
\text { of } \\
\text { tax change }\end{array}$ & $\frac{w c \& w}{w \& w n} \ni \& \frac{1}{*}$ & $\frac{w c \& w(}{w(\& w n} \ni \& \frac{, \&(}{* \&(}$ \\
\hline
\end{tabular}




\subsection{Dalton's law and perfect competition}

Two major questions are important in the analysis of tax shifting. First, under what conditions does tax shifting occur and second, does it matter whether taxes are levied on the demand side or on the supply side of the market concerning the shifting process?

The answer to these questions from the theory of public finance is that if a tax is levied on a free and good functioning market, the final or economic burden of a tax does not depend on the statutory incidence: hence it is not relevant on which side of the market the tax is levied - we call this the independence theorem. This theorem is proved and dealt with extensively in Dalton (1936), Keller (1980), Musgrave and Musgrave (1987), and Stiglitz (1988) - it is also known as Dalton's Law. ${ }^{6}$ A corollary of Dalton's Law is that the final or economic burden of a tax depends on the price elasticities of demand and supply.

Tax shifting usually is analyzed by looking at the effects of marginal changes in taxes and consequently Dalton's Law implicitly refers to changes in the variables of our analysis (see also Keller, 1980; Musgrave and Musgrave, 1987). Since, the distribution of the economic burden can be represented by $\left(w c-w^{*}\right) /\left(w^{*}-w n\right)$ and that of the statutory burden by $(w c-w) /(w-w n)$ - see also Table 1 - Dalton's Law implies:

$$
\frac{d[(w c \& v() /(w(\& w n)]}{d[(w c \& w) /(w \& w n)]} \ni 0
$$

that is, the change in the distribution of the economic burden is independent of that of the statutory burden. After some manipulation it can be shown that this implies that the elasticity of wage costs with respect to net wages is independent of the wedge. ${ }^{7}$ Or that the elasticities of both wage costs and net wage with respect to the wedge are independent of the wedge. We will concentrate in our further analysis on the elasticity of wage costs with respect to the wedge, which is defined by $\mathrm{d} w c / \mathrm{d}(,-*)$ - its independence also implies independence of the elasticity of the net wage. Dalton's Law then requires that wage costs satisfy the following expression:

$$
\text { wc } \ni \text { w } \% x .(, \&) \quad 0 \quad x \quad 1
$$

where $x$ is an arbitrary constant, independent of $(,-*)$.

6 Note that although each well-known textbook in public finance discusses Dalton's law at length, a reference to the original work by Dalton can hardly be found (see e.g. Musgrave and Musgrave (1987) and Stiglitz (1988)). That is why one will search in vain for the expression 'Dalton's law' in such textbooks. It seems that in research papers more credits are given to Dalton's work (see e.g. Keller (1980) and Compaijen and Vijlbrief (1994))

7 Since the variables are in logarithms, the elasticity of wage costs with respect to net wages is given by $\mathrm{d} w c / \mathrm{d} w n$. 
Dalton's Law can be illustrated for a labour market with perfect competition. For simplicity we assume constant elasticities of supply and demand, $\forall$ and $\exists$ respectively. Then the following model results:

$$
\begin{array}{ll}
\left.N^{s} \ni A() . W\right)^{\forall} & \forall>0 \\
N^{d} \ni B(E . W)^{\exists} & \exists<0 \\
N^{s} \ni N^{d} &
\end{array}
$$

The solution for wage costs and employment is: ${ }^{8}$

$w c \ni w(\%[\forall(\forall \&)] .(, \& *)$

$n \ni n(\%[\forall \nexists(\forall \&)] .(, \quad \& *)$

From (7) it follows that the elasticity of the wage costs with respect to the wedge is equal to $\forall /(\forall-\exists)$, hence it is independent of the wedge. Thus equation (3) is satisfied and Dalton's Law holds. Moreover, it can easily be shown that the distribution of the economic burden, $\left(w c-w^{*}\right) /\left(w^{*}-w n\right)$, is equal to the ratio of the elasticities, $-\forall / \exists$. This is consistent with the corollary to Dalton's Law mentioned above.

The shifting parameter is given by:

$$
\text { ( э } \notin \exists((\forall \&)] ., \%[\forall(\forall \&)] . *
$$

From equation (9) one sees that employers will shift more of their burden on employees $((<0)$ as long as the increase in their burden does not exceed the increase in that of employees by a factor $\forall / \exists$. That is as long as , $/ *>\forall / \exists$ holds. Thus the ratio of elasticities of demand and supply plays an important role in the shifting process. This can also be seen from Figure 1 where it cannot be said on beforehand whether the gross wage corresponding to the new equilibrium level E exceeds the original equilibrium level A or not. It is obvious from the figure that this depends on the slopes of the curves, thus the elasticities of demand and supply are important in the determination of shifting. $\left(\mathrm{N}^{*}\right)$ to be $\mathrm{W}^{*}=(\mathrm{B} / \mathrm{A})^{1 /(\forall-\exists)}$ and $\mathrm{N}^{*}=\mathrm{A}^{-\exists /(\forall-\exists)} \cdot \mathrm{B}^{\forall /(\forall-\exists)}$, respectively. 


\section{Wage bargaining and efficiency wages}

In the previous section we discussed Dalton's Law and did show that it holds in a situation of perfect competition. An interesting question then is whether Dalton's Law also holds in a situation of imperfect competition. For that reason we look at two models of wage bargaining and a model of efficiency wages. It will appear that Dalton's Law then only holds under very specific assumptions.

\subsection{Wage bargaining: a simple model}

An early wage bargaining model, which also has been applied to the Netherlands, can be found in Brandsma and Van der Windt (1983) and Knoester and Van der Windt (1987). In that model it is assumed that wages result from bargaining about wage claims of employees and wage offers of employers. Wage claims ( $W^{c l}$ is the gross wage claim in real terms) from employees result from the notion that the labour share in national income (W.N/Y) should at least be equal to N. Moreover, employees calculate in terms of net wages. Hence the real wage claim is:

$$
\left.W^{c l} \ni(1 /)\right) \mathrm{N} / \mathrm{N} \quad 0 \# \mathrm{~N} \# 1
$$

Wage offers ( $W^{o}$ is the gross wage offer) from employers result from profit maximising behaviour, given a CES production structure. Employers take wage costs into account in the bargaining process. Hence, the wage offer is:

$$
W^{o} \ni(1 / E) c .[Y / N]^{1 / \Phi} \quad \Phi<1
$$

where $\mathrm{c}$ is a constant and $\Phi$ is the elasticity of substitution: the latter is assumed to be smaller than unity.

An important assumption of the model is that employers set employment before the wage bargaining process starts. Hence wage offers and wage claims are made while employment is given. The bargaining process results in a gross wage which is the geometric average of wage offers and wage claims, with weights $\mathrm{P}$ and (1-P) representing the bargaining power of employers and employees, respectively. The higher $\mathrm{P}$ is, the higher the bargaining power of employers. We can write this as follows:

$$
W \ni\left(W^{c l}\right)^{1 \otimes} \cdot\left(W^{o}\right)^{\mathrm{P}} \quad 0 \# \mathrm{P} \# 1
$$

It is assumed that in the next period employment is adjusted to the demand for labour consistent with the current new wage rate. Then new wage claims and offers result.

Solution of equations (10) - (12) yields for wage costs:

$$
\text { wc э } w(\%(1 \& \mathrm{P}) .(, \& *)
$$

We can now analyze the effects of employees' taxes and of employers' contributions. From equation (13) it follows that both an increase in employees' taxes and an increase in employers' contributions have a positive effect on wage costs. Note the important role of $\mathrm{P}$, the bargaining power. If employers have all bargaining power $(\mathrm{P}=1)$ then wage costs are not affected neither by employers' nor by employees' taxes. Further, Dalton's Law holds in this model too: from equation (13) one sees that equation (3) is satisfied. Hence it does not matter which side of the market is taxed. This can also be seen from the distribution of 
the economic burden, which is equal to the ratio $(1-\mathrm{P}) / \mathrm{P}$. Hence the distribution is independent of $*$ and

The net-result of a change in employers' and employees' contributions and taxes follows from (, which can be derived from equation (13):

$$
\text { ( э P., \%(1 \&P).* }
$$

From equation (14) one sees that employers will shift more of their burden on employees as long as the increase in their burden does not exceed the increase in that of employees by a factor (1-P)/P. That is as long as,$- / *<[(1-\mathrm{P}) / \mathrm{P}]$ holds. Thus the bargaining power plays an important role in the shifting process.

\subsection{A right-to-manage model of wage bargaining}

The development of employment is unclear in the previous model. It is a model of wage determination, without explicitly paying attention to employment. We therefore develop a bargaining model, somewhat similar to Knoester cs., in which employment is not assumed to be constant but is determined from profit maximization. Moreover, we assume a right-to-manage structure, that is employers set employment after wage bargaining has taken place. Finally, we derive the solution for the wages from a specific bargaining solution, the Nash bargaining solution.

As mentioned above, employers aim at maximal profits. However, there is a minimum acceptable level of real profits, which is a fraction $\Pi$ of real income. Hence, the maximum wage offer is

$$
W^{o} \text { э }(1 \& \Pi Y / N \quad 0 \# \Pi \# 1
$$

The minimum acceptable level of real profits constitutes a threat point in the bargaining process over wages.

Employees are assumed to aim at a maximal wage sum. Moreover, they also have a threat point in the bargaining process, which results from the notion that the labour share in national income should at least be equal to $\mathrm{N}$. Hence the minimum acceptable real wage is:

$$
W^{c l} \ni \mathrm{N} / \mathrm{N} \quad 0 \# \mathrm{~N} \# 1
$$

It is assumed that the threat points are consistent, i.e. $\Pi+\mathrm{N} \# 1$.

Let the Nash solution provide a good description for the solution of the wage bargaining process. Hence, if we include taxes, wage bargaining aims to solve the following problem:

$$
\left.\max _{W} G(N, W) \ni\{(1 \&] . Y \& E . W . N\}^{\mathrm{P}} \cdot\{) . W \cdot N \& \mathrm{~N} Y\right\}^{18 \mathrm{P}} 0 \# \mathrm{P} \# 1
$$

$$
\text { S.T. YIN э c. }(E . W)^{\Phi}
$$

In equation (17) the parameter $\mathrm{P}$ indicates the bargaining power: a higher $\mathrm{P}$ represents more employers' power. The variables $\Pi \mathrm{Y}$ and NY are the threat points of employers and employees, respectively. Equation (18) is the demand function for labour, which poses a constraint to the maximization process. 
Maximization of the Nash function results in wage costs given by:

$$
w c \ni w(\%(\Lambda \& \Lambda) /(1 \& \Phi
$$

where $\delta=\ln \left[1-\Phi . N \cdot G_{N} / W \cdot G_{W}\right]$ and $\delta^{*}=\ln \left[1-\Phi . N \cdot G^{*}{ }_{N} / W \cdot G^{*}{ }_{W}\right]$; an asterix refers to the situation in absence of taxes. ${ }^{9}$

Actually the solution as presented in equation (19) holds for any specification of the function $G(W$, $N$ ), and hence can be applied to much more bargaining situations than the one sketched here. As one can see from equation (19), the impact of the wedge, if any, results from its impact on the elasticities of the target function, $G(W, N)$.

When we confine ourselves to the specification in equation (17), a further elaboration of the terms $\delta$ and $\delta^{*}$, leads to a rather complicated expression. However, this is mainly due to the inclusion of threat points. In the absence of threat points, we find:

$$
\text { wc э } w\left(\ni \frac{1}{1 \& \Phi} \ln c .(1 \& \Phi) .(1 \& \mathrm{P})\right.
$$

hence $w c=w^{*}$. When employers have full bargaining power, $\mathrm{P}=1$, this result is intuitively very plausible: the employers will shift all taxes backwards towards the employees, hence $w c=w^{*}$ and $w n=w^{*}{ }_{-},+*$. The reason why this result also should hold when employees have full bargaining power, $\mathrm{P}=0$, is less intuitive. ${ }^{10}$ To explain this we present the demand curve for labour $n^{d}$ in Figure 2. In the case of employees having full bargaining power, we have a situation of bilateral monopoly. The preferences of the workers are indicated by indifference curves like $\mathrm{I}_{1}, \mathrm{I}_{2}$ and $\mathrm{I}_{3}$ in the figure - consistent with the goal of a wage sum ).W.N. ${ }^{11}$ Since unions aim at a maximal wage sum, they will choose in absence of taxes point A, with wages $w_{2}$ and employment $n_{2}$. When taxes are levied on employees, one might expect that employees shift these forward towards employers when they have full bargaining power, and hence an increase in wage costs will be the result. However, one should realize that given the demand curve for labour of the employers, such an increase in wage costs always will be accompanied by a lower employment and a smaller wage sum. ${ }^{12}$ Hence employees will not prefer the situation with the lower employment and remain in point $\mathrm{A}$. When in this case taxes are levied on employers, the demand curve for labour will shift vertically downwards by exactly,; it is represented in Figure 2 by $n^{d^{\prime}}$. Therefore the employees will choose

9 The equilibrium wage is given by $w^{*}=\left(\ln c+\delta^{*}\right) /(1-\Phi)$ and $w c=(\ln c+\delta) /(1-\Phi)$ holds. The symbols $G_{N}$ and $G_{W}$ refer to the partial derivatives of equation (17) with respect to $N$ and $W$, respectively. These are still functions of $W$.

Maybe that is the reason it is not recognised by Lever (1991) who derives a model along the lines sketched here, but without further arguments then superimposes a different impact of employers' and employees' taxes.

11 This implies that in terms of logarithms the indifference curves are straight lines. The concavity of the demand function for labour is due to the property of $\Phi<1$ - cf. equation (18).

12 It is important to realize that we assume that the preference structure of the employees is not affected by the change in taxes: in terms of Figure 2, the relevant indifference curves remain $\mathrm{I}_{1}, \mathrm{I}_{2}$ and $\mathrm{I}_{3}$, but they now represent different levels of the wage sum. 
a new wage, $w_{1}$, which is at the same level of employment, $n_{2}$ - cf. point $\mathrm{B}$. The wage costs then remain $w_{2}$, which is also the wage in absence of taxes.

Figure 2 Taxes and the right-to-manage model

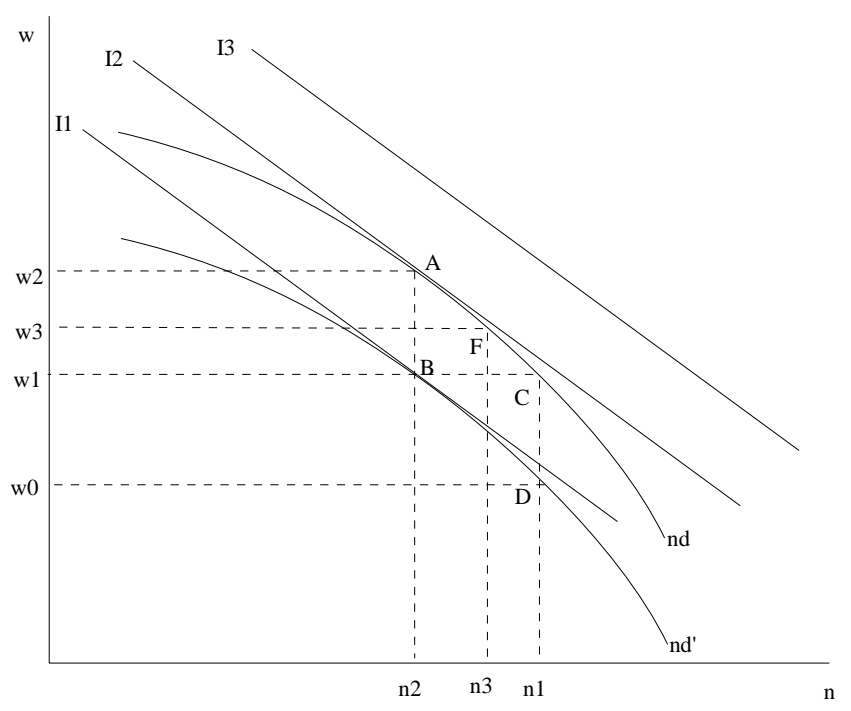

We now turn to

the case of the employers having full bargaining power. Let us assume that for some reason employers choose point $\mathrm{C}$ when they have full bargaining power - hence employment is at $n_{l}$ and the wage rate is $w_{l}$ . When taxes are levied on employers, the demand curve for labour shifts towards $n^{d^{\prime}}$. When employers have full bargaining power, they will decrease the wages towards $w_{0}$ and maintain both employment and wage costs at point $C$. From these results one might be inclined to expect that also in the intermediate case, where neither employers nor employees have full bargaining power, $w c=w^{*}$ will be found. This is the case indeed. ${ }^{13}$

When we include the threat points, equation (20) becomes a much more complicated expression, in which the wedge appears prominently.

It can easily be derived that Dalton's Law then no longer holds too. In terms of Figure 2, this can be explained by the observation that the indifference curves no longer are straight lines due to the inclusion of the threatpoint. Hence shifts in the demand curve for labour, due to employers taxes, or in the isoquants, due to employees taxes, will lead to points of tangency which no longer lie above each other as is the case in the absence of threatpoints. This implies that it will matter which side of the market is taxed.

\subsection{The case of efficiency wages}

13 Note that in concluding $w c=w^{*}$ when either employers or employees have full bargaining power, we do not claim that both cases result in the same costs. In case employees have full bargaining power, $w^{*}=w_{2}$ and in case employers have full bargaining power, $w^{*}=w_{1}$ and note that $w_{2}>w_{1}$. 
The models discussed above have often been used in empirical research. Models that discuss the influence of taxes on efficiency wages are of a more theoretical character, however. We will briefly discuss a model here, based on Hoel (1989). Hoel analyses the consequences of changes in taxes in an efficiency wage framework. Starting point of the analysis is the effort function, which is defined as:

$$
\text { e э ().w, ).W, U), with } e_{1}, e_{3}>0, e_{2}<0
$$

where e stands for effort, $\mathrm{w}$ is the gross wage of the firm, $\mathrm{W}$ is the average wage elsewhere in the economy and $\mathrm{U}$ is unemployment. ${ }^{14}$ One should realize that due to progressiveness in the tax system, employees' contributions can be a function of wages.

This effort function expresses first that effort depends on after tax wages. Second, it incorporates the idea that effort depends on the relative wage for it contains both the wage of the firm and the wage elsewhere in the economy. Again, mind the framework of the analysis. Hoel assumes a representative firm, faced with an effort function like (21). It will be clear that in this framework equilibrium will occur when all firms pay the same wage, hence when $\mathrm{w}=\mathrm{W}$. Further, it will be clear that the effects that are calculated by Hoel are economy-wide effects.

If the firm strives after cost minimization, the wage is determined such that the following (Solow) condition holds:

$$
e_{1} \frac{) w}{e} s(w) \ni 1
$$

with $s(w)=[\{d() w) / d w\} .\{w /() w)\}]$, the elasticity of the after-tax wage with respect to the pre-tax wage. Note that $s(w)$ reveals the progressivity of the tax system: if the system is based on proportional taxes, $s(w)$ $=1$. However, if the system is progressive the increase in the after-tax wage is less than proportional with an increase in pre-tax wages and hence $s(w)<1$.

Note that in absence of taxes, i.e. $)=1$, the usual Solow condition appears $\left(e_{1} w / e=1\right)$. When comparing this condition with equation (22), one sees that in the Hoel model the influence of taxes is twofold. The first impact is through the effort function, since effort depends on net wages, and the second occurs through the progressiveness of the tax function. The influence of the progressiveness is especially interesting because we have not discussed the progressiveness of the tax system in the previous models. We will therefore take a closer look at the role of the progressiveness of the tax system. If taxes are proportional $s(w)=1$, the Solow condition boils down to the idea that the elasticity of the net wages with respect to effort is equal to 1 . Note that in a proportional tax system an $\mathrm{x} \%$ increase in gross wages implies an equal $x \%$ increase in net wages. Hence, it does not matter whether the employers look after the gross wages and the employees look after the net wages. However, if the tax system is progressive, an $\mathrm{x} \%$ increase in gross wages implies a less than $\mathrm{x} \%$ increase in net wages. Consequently, the aforementioned elasticity must exceed 1 . For, the employers will reach an optimum when an increase in the pre-tax (gross) wages will cause an equiproportionate increase in effort. But since the corresponding increase in net wage is less than proportional to the gross wage increase, the elasticity of effort with respect to net wages will have to exceed 1 in the optimum. This implies that the net wage will have to be lower in equilibrium. An increase in the marginal tax rate, while keeping the average tax rate at the initial equilibrium wage constant, will cause a decrease in the wage rate. 
When we concentrate on the effects of a change in the average tax rate, the specification of the effort function is important. Only if the impact of gross firm wages is always considered relative to average wage in determining effort, ${ }^{15}$ a change in the tax level leaves the equilibrium wage and unemployment rate unchanged. This is obvious, since in this case a change in the tax rates does not influence effort and hence the wage rate. However, when for instance there is no external wage incorporated in the effort function, the same results will be found as in the case when marginal taxes change.

This analysis ignores any change in employers' contributions, „, because effort is not influenced. Hence Dalton's Law will not hold: it definitely does matter which side of the labour market is taxed.

\section{The development of the wedge in the Netherlands 1960-1993}

In discussing the influence of the wedge on wage formation, it is interesting to look at the magnitude and the development of the wedge for the Netherlands. Moreover, we can analyze to what extent the tax reform in 1989 - the so-called Oort - operation has influenced the magnitude or the composition of the wedge. It should further be noticed that it was explicitly stated that the Oort-operation should be neutral with respect to revenues.

Implicitly it was also assumed that the composition of the wedge did not matter: within the total wedge shifts from employers' contributions to those of employees (the famous 'brutering') were assumed to have no serious repercussions. That is, Dalton's Law was assumed to hold. We shall show below that the composition of the wedge changed considerably due to the Oort operation. We will elaborate the possible consequences of this change in the next section, where we discuss empirical results with respect to tax shifting in the Netherlands.

In section 2 the wedge is defined as the ratio between the wage costs for the employer and the net wage received by the employee. However, it is more common to look at the difference between both and relate this difference to the gross wage. This difference consists of three parts: employers' contributions to social security funds (also known as payroll taxes), employees' contributions to social security funds and income taxes paid by employees.

In most research the national accounts are used as the source of information about taxes and social security contributions when measuring the wedge. These aggregate figures provide a measure at the macrolevel. However, since these figures can only show a rough and average development, it might be interesting to measure the wedge also at the level of an individual. Let us start with the latter and thereafter discuss the aggregate figures.

It will be clear that the wedge differs between individuals. Taxes and premiums depend on income and in the Dutch system there is a maximum income level above which no premiums are indebted. Consequently, measuring the wedge at the level of individuals boils down to the calculation of taxes and premiums for a certain type of household with a certain income and then calculate the ratio of the wedge to the gross wage. ${ }^{16}$ Along these lines, the Dutch Ministry of Finance has been able to measure the wedge for several

15 More precisely, if the effort function is specified such that it is homogeneous of degree zero in its first two arguments.

The calculations are to a certain extent arbitrary, since one has to make assumptions concerning interest deductions, travelling costs etc. for the individual.This means that given a certain gross wage, one has to calculate the corresponding net wage and wage costs using tax tables and 
income groups and several types of households (Krapels en Van Ravestein (KR), 1987). They present data covering the period 1960-1987 and the series have been updated by us for the period 1988-1993, using the same method. Figures $3 \mathrm{a}-3 \mathrm{c}$ show the results for a family type with a 'modaal' income and having 2 children. We will discuss these results below.

Figure 3a Employers' part of the wedge

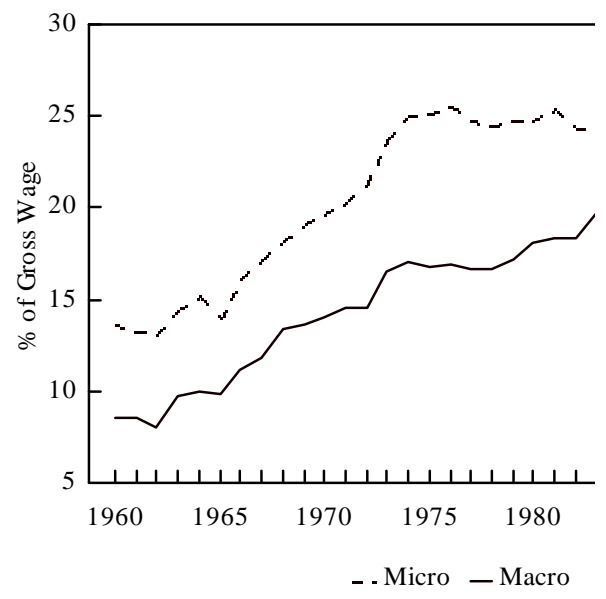

schemes for premiums for social security, both for employers and for employees. In the calculations we abstract from specific circumstances. 
Figure 3b Employees' part of the wedge

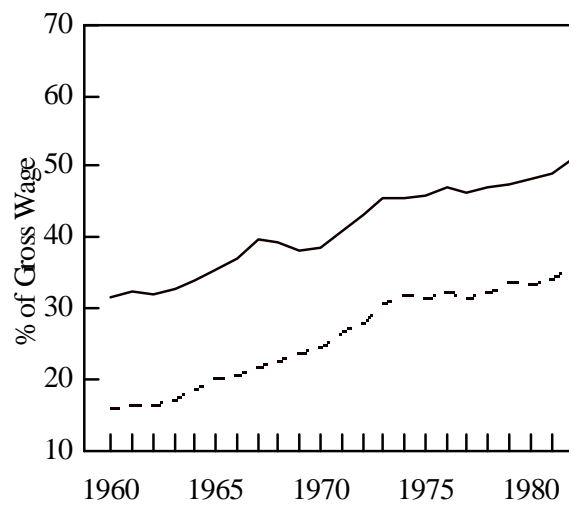

- - Micro - Macro

Figure 3c Total wedge

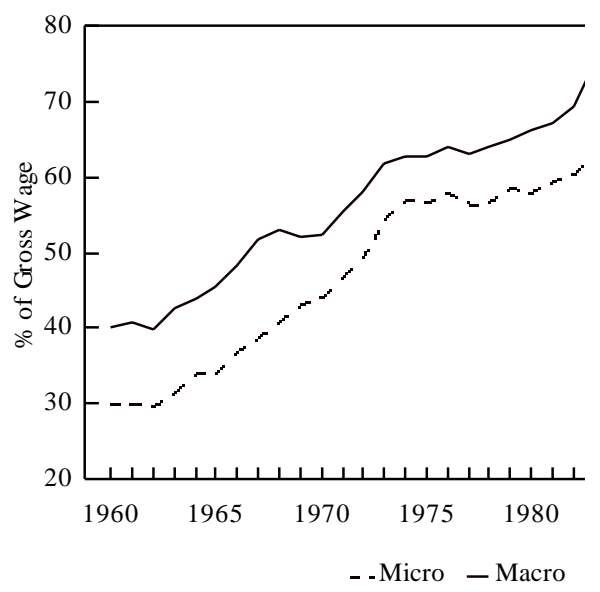

Sources: The micro-data are based on F.J. Krapels and A. van Ravestein (1987), page 47. The figures from 1988-1993 have been constructed by the authors, using the same method. The macro-data have been derived from the various volumes of the national accounts. 
When the wedge is measured at an aggregate level (the macro-wedge), the main problem is that the national accounts in the Netherlands only provide data on taxes at the level of families. Hence aggregate figures for wage and income taxes of employees are not published. For that reason we have taken 'families' as an approximation of employees, which is in line with other empirical research in this field. ${ }^{17}$ Social security contributions are split up into employees' and employers' parts. Further, since Krapels en Van Ravestein have excluded pension premiums, we have excluded them too in our calculations for reasons of comparability. The results of these calculations are also presented in Figures 3a-3c.

We have plotted both the micro-wedge and the macro-wedge in one figure. This may suggest that one can easily compare these figures. One needs to be careful in this respect, however. First consider the employees' part. We have calculated the micro burden by using the tax tables and the tables for premiums for social security and apply them to a person having a modal income. Hence the micro-wedge measures the average statutory burden on a certain class of income, the modal income. To calculate the macrowedge, we have traced the total amount of taxes paid by households and premiums not paid by employers, and divided this amount by the total gross wages that is received by households. Consequently, the macrowedge measures the average 'collective' burden per guilder gross income that has been earned in the private or in the public sector. In a sense this is an approach of the statutory burden at the macro-level. In comparing these figures, four fallacies need to be stressed, however. First, note that in the macro-wedge all payments for taxes and premiums are included, not only the payments of employees. Taxes and premiums that are paid by people that receive some kind of benefit or pension is included in the tax payments, but their income is not included in total gross wages. Hence, this provides an upward bias in the macro-wedge in comparison to the micro-wedge. Lack of reliable data does not permit us to do more precise calculations in this respect. Second, the macro-wedge measures the taxes that have actually been paid. It is obvious that because of (il)legal tax deductions the taxes that are actually paid differ from the taxes that we have levied according to the tables (cf. footnote 16). This produces an upward bias in the micro-wedge. Third, in the Dutch system, taxes are progressieve and premiums for social security contributions are degressive (i.e. proportional to a certain maximum). Both the progressivity and the degressivity are fully incorporated in the macro-figures, but not in the micro-wedge, since modal income is not liable to the highest tax-tariff and is slightly below the maximum income for levying the premiums. The influence on the comparison of the micro and the macro figures is ambiguous. Fourth, we have constructed our modal income by applying indices for contract wages to a modal wage in one year, while the total gross wage in the national accounts is the sum of the wages that is actually paid. As far as the development of the modal income differs from the development in total gross wages, there will be a bias. Let us for example assume that tax shifting occurs. As far as the effects of tax shifting with respect to the total gross wages differs from the effects on the modal wage, this will cause an extra complication too in comparing the macro and the micro-wedge. To summarize, only when there exists one flat tax rate, and when tax deductions are simply applicable and unambiguous (e.g. as in the case of a lump-sum tax deduction), and we can split in employees'households and other households, and when the development of the modal income exactly matches the development of total gross wages, the macro and the micro wedge will be identical. These problems are less severe in the employers' part of the wedge. Premiums only concern employees and there are no deductions. Hence the difference between the macro and the microwedge is mainly due to differences in the development of the modal income and total gross wages and the degressivity of the premiums system. 
Figures 3a-3c illuminate some interesting developments. A striking feature is the major changes have taken place from 1989 to 1991 . As De Kam (1996) has already extensively discussed, the Oortoperation started in 1989. A major change was the significant shift of employers' contributions to employees' contributions of part of the premiums for social security and this operation was accompanied by an increase in gross wages. This resulted in a drastic shift in the composition of the wedge in 1989 and 1990. The Figures show these shifts clearly, especially in the micro-data. At the macro level, employees' premiums and taxes increased from 50\% to 58\% of gross wages in the period 1989 - 1991. During that period employers' premiums decreased from $18 \%$ to $8 \%$.

Apart from these shifts, some interesting developments can be observed. First, the employees' wedge shows an increasing trend over the whole period, while employers' contributions stabilise from 1975 onwards. Thus a shift from employers' to employees' contributions has taken place during the last fifteen years. If we compare the share of employees' premiums (no taxes) with the share of employers' premiums, we notice an increase from 11\% to 32\% in employees' contributions during the period $1960-1993$ and an increase in employers' contributions from 8\% in 1960 to $17 \%$ in 1974, which stabilizes till 1989 (aggregate figures). Note that this expresses the shift in statutory burden that has taken place from employers' to employees' contributions.

Second, contrary to what we notice for the employees' case, the employers' ratio of premiums to gross wages at the micro level is higher than at the macro level. This reflects the fact that in the Dutch system there is a maximum income for the levying of premiums. This income is slightly higher than 'modaal', so for our family with the 'modaal' income this maximum income does not matter. However, for all incomes above 'modaal', the ratio of premiums to gross wages will decrease when income increases. This, of course, influences the macro figures. Moreover, the employees' part of the wedge also measures income taxes for which a maximum income obviously does not hold. On the contrary, the tax system in the Netherlands is progressive. The figures indeed show that the difference between the macro level and the micro level is mainly caused by a difference in the taxes/gross wage ratio.

Third, during the period 1960 - 1993 the total wedge, relative to the gross wage, has increased from 40\% to 66\% (aggregate figures): in 1993 the majority of the wedge consists of employees' premiums, 58\%points (of which 26\%-points consist of taxes) and only 8\%-points are employers' contributions.

An interesting conclusion which can be drawn from this analysis of the data is that the Oortoperation has accentuated the shift in the composition of the wedge which already took place from the midseventies onwards. Given our theoretical considerations in the previous section, such a shift might have consequences for wage formation in the Netherlands. For an evaluation of these consequences, we have to look at empirical estimates. This will be the subject of the next section. 


\section{Empirical results for the Netherlands}

In section 3 we have analyzed the role of taxes and contributions for social security. We did show that in many cases Dalton's Law did not hold and hence it does matter whether employees or employers are taxed. The question remains, however, to what extent this is relevant for the Netherlands. In this section we start with an overview of empirical results for the Netherlands, based on the models discussed in section 3. For obvious reasons we will concentrate on the impact of employees' and employers' taxes in the Netherlands. It is clear that when different coefficients are found (or used), Dalton's Law is violated. The relevant coefficients of the various estimates of a wage equation are summarized in Table 2 . The coefficients reported in that table represent the extent of shifting, measured by the elasticity of the wages with respect to employers' resp. employees' premiums.

Next we present estimation results based on our own research for the Netherlands and we end with some remarks with respect to the impact of the Oort operation.

\subsection{Earlier research for the Netherlands}

Tax shifting research has been numerous in the Netherlands. In most cases an expression for wages is derived from a bargaining or a wage setting model. The general expression for the wage equation is

$$
w c \text { э } w(Y / L, p, U, . .) \% c_{1}, \& c_{2} *
$$

and the first term at the right hand side of (23) expresses the idea that wages depend on labour productivity, on prices, on unemployment and other factors that differ between the various models. For our purpose, $c_{1}$ and $\mathcal{G}$ are relevant. $c$ measures the elasticity of the wages with respect to employers' premiums. Note, that when $c_{1}=1$, the change in the wage cost is equal to the change in the employers' premiums: hence there is no employers' shifting. Further, since $*$ is the retention ratio, a decrease in $*$ implies an increase in employees'part of the wedge.

Table 2 Tax elasticities

Model Employers Employees Wedge Period

$\begin{array}{lcccc}\text { FK } & 0.85 & 0.25 & & 1954-1975 / 1978 \\ \text { FKSEC } & 0.80 & 0.36 & & \\ \text { MORKMON I } & & & 0.46 & 1970: \text { I - 1979: IV } \\ \text { MORKMON II } & 0.90 & 0.69 & & 1971: \text { II - 1987: IV } \\ \text { CESAM } & 0.86 & 0.43 & & 1958-1985 \\ \text { Knoester/V.d. Windt } & & & 1.15 & 1958-1981 \\ \begin{array}{l}\text { Van Veen/V.d. Veen } \\ \text { Mulder }\end{array} & 0.83 & 0.28 & & 1960-1980 \\ \text { Graafland (1990) } & & & 0.63 & 1958-1987 \\ \text { Graafland (1991) } & 0.91 & 0.40 & 0.46 & 1966-1988 \\ \text { Lever 1.00 } & 0.28 & & & 1966-1987\end{array}$


The models that are most heavily used in economic policy are the FK/FKSEC model from the Central Planning Bureau and MORKMON from the Dutch Central Bank. Together with the CESAM model from the universities of Groningen and Twente, they belong to the large macroeconomic models for the Netherlands.

When we look at the way tax shifting is modeled, we find that in the FK model it is assumed that the elasticities of employers' premiums and employees' premiums with respect to wage costs are 0.85 and 0.25 , respectively. In the multi-sector version of this model, the FKSEC model, these elasticities are estimated coefficients, with values 0.80 and 0.36 , respectively.

The first version of the MORKMON model, MORKMON I, shows an elasticity of the total wedge of 0.46. Note that, in using the total wedge, it is implicitly assumed that employers' and employees' burden have a symmetric effect. Unfortunately without argument, this assumption is dropped in the MORKMON II model. ${ }^{18}$ The results of the MORKMON II model show long run elasticities of 0.90 and 0.69 , respectively. These results seem to confirm the decision to drop the symmetry assumption.

Finally, estimation results of the CESAM model are 0.86 and 0.43 , respectively.

When we turn to specific studies, Knoester en Van der Windt (1987) have developed a bargaining model, without right to manage. In their estimates the authors do not distinguish between employees' taxes or employers' premiums. ${ }^{19}$ They estimate the elasticity of the total wedge with respect to the wage costs and find a coefficient of 1.15. The magnitude of the coefficient is high: this 'overcompensation' is not found in other research. Van Veen and Van der Veen (1988) estimated simultaneously a wage and price equation. Their estimates concern the development of the gross wage and are based on a Knoester type of model. They find elasticities of 0.83 and 0.28 for employers' taxes and employees' taxes, respectively. Mulder (1990) who also estimated a wage equation with the total wedge, distinguishes between short-term and long-term shifting. The short-term elasticity of the wedge is 0.33 , the long term elasticity equals 0.63 . The increase in the value from the short-term to the long-term is consistent with the conjecture of Blinder that we have discussed in the introduction. Graafland (1990) derives a wage equation from a (bilateral monopoly) right-to-manage model, with insiders and outsiders. He finds an elasticity of the total wedge of 0.46 .

Graafland (1991) develops a right-to-manage model in which employers' and employees' taxes have been separated. Moreover, his model incorporates both average and marginal tax rates. His results for average taxes are in accordance with the bilateral monopoly model with right-to-manage - cf. section 3.2 while his results with regard to marginal taxes are in line with the model of Hoel - cf. section 3.3. For the average tax rates he finds elasticities of 0.91 and 0.40 for employers and employees, respectively. ${ }^{20}$ For the marginal tax rate of employees, he finds an elasticity of -0.11 .

It is interesting to note that in none of these macroeconomic models a theoretical motivation is given for the distinction between employers' and employees' premiums. FKSEC even states: 'Although theoretically difficult to justify, the distinction consistently appears to be relevant empirically ...' (p.31).

As we explained in section 3.1, Dalton's Law holds in their model - although the authors do not claim this.

He states that these coefficients do not differ significantly from each other. In his opinion this is consistent with his theoretical model. However, he does not realize that wage bargaining is about gross wages and not wage costs, compare equations (17) and (18) above. The analysis of section 3.2 shows that then Dalton's Law only holds under very special circumstances. 
Lever (1991) also estimates a bilateral monopoly model. He finds an elasticity for employers' premiums equal to 1.0 , whereas the elasticity for employees' premiums $(0.28)$ is not significant from 0 . Hence, he finds that employers do not succeed in shifting increases in employers' premiums backwards nor does forward shifting occur. ${ }^{21}$

From these results we can conclude that Dalton's Law probably does not hold for the Netherlands: it seems to matter which side of the market is taxed. In particular in the three macroeconomic models this result is consistently found. Although the results do vary, it does not seem unreasonable to assume that about $15 \%$ of employers' taxes is shifted backwards and about $35 \%$ of employees' taxes is shifted forward.

\subsection{An extension of the empirical analyses}

As it follows from Table 2, most empirical estimates cover the period 1960 - 1985. In our empirical analysis we have extended the estimation period to 1960-1993. This is interesting for two reasons: first, we can check the robustness of the estimation results and second, as can be seen in the Figures 3a to 3c, there has occurred a major change in the composition of the wedge from 1990 onwards.

Since the Lever model could best be analyzed, we have chosen to use this model for our estimates. Lever has developed a model of union wage formation and labour demand, based on the monopoly union model (Lever, 1993, p. 32). The employment equation (n) is derived from a constant returns to scale production function of the CES type and using the marginal productivity condition. To derive the wage equation, Lever uses the monopoly model. The union maximizes a utility function with wages and employment as the arguments. The weight that the union attaches to employment depends on its turn on aggregate short term unemployment ( $\mathrm{u}-\mathrm{ul}$ ) and the replacement ratio (b). Next, the wage equation is augmented with employers' (,) and employees' taxes (*) (including contributions for social security).

21 Although Lever does not recognise this, these results are consistent with his model. His results are consistent with equations (19) and (20) above. However, Lever does not recognise that the parameter ) does not appear in these equations. Consequently a coefficient of 0 for that parameter is not surprising. 
From this model the following labour demand and wage equation are derived: ${ }^{22}$

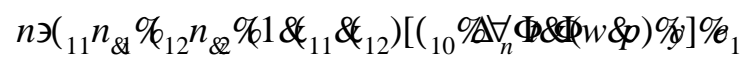

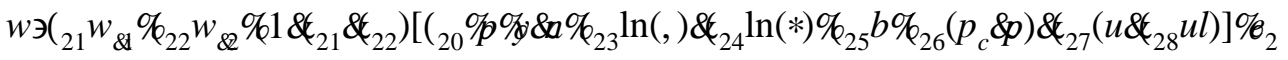

In this model full shifting of employers' taxes occurs when $\left(_{23}=0\right.$ (no shifting when $6_{3}=1$ ) and full shifting of employees' premiums when $\left(_{24}=1\right.$ (no shifting when ${ }_{24}=0$; recall that $*$ is the retention ratio). If employers do not succeed in shifting, an increase in their part of the wedge causes an increase in wage costs.

We have first reproduced the Lever data and his estimates for the period 1965-1987. Our results closely resemble the Lever results and we have concluded that our method of reproducing the data and estimation technique could be used to extend the Lever results to a longer period. ${ }^{23}$

We have investigated the sensitivity of the results, both for the Lever estimates and for our estimates. First, since we have used a 3SLS technique, we have varied the instruments. These exercises showed that the results are rather robust concerning the use of the instruments. Second, Lever has pegged the coefficient of the employers' premiums $\left(\left(_{23}\right)\right.$ to 1 . This implies that wage costs increase by the same amount as employers' taxes and hence there is no shifting of employers' taxes. We have estimated this coefficient freely in a number of specifications and found that this coefficient indeed is close to 1, but the results deteriorated ("wrong" signs in general, insignificance of coefficients). We would have liked to test whether pegging to 0.85 (the "average" result for the Netherlands) is better than pegging to 1, but we could not find any test for this.

Next, we have estimated these equations for the period 1960-1993. The results worsened (in comparison to the period 1965-87). This was surprising. However, since major changes have appeared in 1989/1990 (see previous section), we tried whether confining ourselves to the period 1960-1990 would improve the results. ${ }^{24}$ It appeared, however, that the equations explained best for a subperiod, the period 1969-1990. It is not clear on beforehand why this is the case. One guess might be that only from 1964 onwards, free and normal wage bargaining was incorporated in the Dutch labour relations. In the early sixties (1963) the

For more details we refer to Lever, 1993, chapter 3. As one can notice in equation 24 and 25 , it is assumed that labour demand and the wage rate follow an AR2 process to the equilibrium values. Further, note that all variables are in $\ln$ (except for $u$ and $b$ ). In the employment equation, $\forall_{\mathrm{n}}$ is the labour augmenting technical progress and $\Phi$ is the elasticity of factor substitution and equals $1 /(1-\Delta), \mathrm{p}$ is production prices and $\mathrm{y}$ is real income. In the wage equation $\mathrm{w}$ is the wage costs (including all taxes), and, and $*$ are defined as before. Note further that we have rewritten the wage equation in terms of , and $*$.

We would like to thank Marcel Lever for providing us with part of the data. Note that the data are only for the private sector. The equations have been estimated with the 3SLS technique in TSP 4.1. We have used the lagged independent variables as instruments.

Of course, it is debatable what "better" results are. We have used two criteria: the signs must be in accordance to the theoretical expectation and second, we have taken a higher significance (tvalues) as a better result. 
famous guided wage policy stopped and in the aftermath of this, we have seen huge wage increases. We also investigated which subperiod within the period 1963-1993 would provide the best results. It then appears that the "best" results were reached for the period 1970-93. Hence, substituting the period 19651987 for 1970-1993 yields better results despite the changes that took place in 1989/1990: employers' premiums decreased and employees' premiums increased. As a check for this result we have performed a Chow test to check whether there has been a structural change in the coefficients during the period 197093. All test were negative and consequently we have not found any structural change. Finally we want to note that the results of the employment equation have been rather robust during all our estimates.

The estimation results for the period 1970-93 are presented in Table 3.

Table 3: Estimation Results, using the Lever equations, period 1970-1993

Employment equation

(11

$\begin{array}{ll}(21 & -0.508\end{array}$

$\left(\begin{array}{ll}10 & 2.35\end{array}\right.$

$\begin{array}{ll}\Delta & -0.67\end{array}$

$\forall_{\mathrm{n}} \quad 0.03$

Wage equation

$\begin{array}{ll}\text { (21 }_{21} & 1.03\end{array}$

$\begin{array}{ll}22 & -0.502\end{array}$

$\begin{array}{ll}{ }_{20} & 6.255\end{array}$

$\begin{array}{ll}23 & 1.00\end{array}$

$\begin{array}{ll}l_{24} & 0.306\end{array}$

$\begin{array}{ll}(25 & 0.038\end{array}$

$\begin{array}{ll}(26 & 0.399\end{array}$

$\begin{array}{ll}(27 & 3.24\end{array}$

$\begin{array}{ll}28 & 0.15\end{array}$

$\mathrm{T}$-values are given between parentheses.

The results of the employment equation show a technical progress of about $3 \%$ per year and a factor substitution elasticity of -0.67 . With respect to the wage equation, our conclusions are similar to the results that are found by Lever. Concerning the tax variables, we have also fixed the coefficient of employers' taxes to 1 . We find slightly higher forward shifting, $30.6 \%$, but more important, the significance of the coefficient has significantly increased. As in Lever, the replacement ratio shows a low and insignificant coefficient. The same holds for long-term unemployment. The t-value of the producers'price gap has decreased however, while the value of the coefficient is more or less in the same range.

From our empirical research we conclude that the results of Table 2 are rather robust. Employers do not succeed in much shifting of taxes, while employees succeed to forward shifting of about $30 \%$ of an increase in taxes. However, in a number of cases, shifting coefficients need to be pegged to reach plausible results. Further we note that different periods provide different results. It is difficult to find 
consistent estimation results for the total period 1960-1993. Our conclusion can certainly not be that it is easy to find empirical evidence for either the absence or the presence of shifting behaviour.

\subsection{The impact of the Oort operation}

It is interesting to apply these findings for the Netherlands to the results of the Oort-operation as presented in the previous section. There we found a shift in the composition of the wedge. At the macro level, employees' premiums and taxes increased from 50\% to 58\% of gross wages in the period $1989-1991$. During that period employers' premiums decreased from $18 \%$ to $8 \%$. Hence a shift of about $10 \%$-points of gross wages took place from employers to employees.

It probably was assumed that this shift was wedge neutral, and hence would not affect wages. This is consistent with Dalton's Law. However, the findings above indicate that this Law does not hold, hence the wages will be affected. A decrease of employers' premiums by $10 \%$-points, corresponds to a growth rate of , of $-8.5 \%$. Given an elasticity of 0.85 , this then would lead to a decrease in wage costs of $7.2 \%$. The increase in employees' taxes and premiums by $8 \%$-points corresponds to a growth rate of $*$ of $-16 \%$. This then would lead, given an elasticity of 0.35 , to an increase in wage costs of $5.6 \%$. The net result then would be a decrease in wage costs of $1.5 \%$. This is approximately neutral.

One should realize that this result is not consistent with Daltons Law. For, when shifting would be neutral, with an elasticity of about 0.5 - cf. Table 2 - the net effect of the Oort operation would be an increase in wage costs of $3.75 \%$.

\section{Concluding remarks}

In this paper we discuss an old question: does it matter which side of the market is taxed? The relevance of this question stems from the ongoing trend in the Netherlands which shows a shift from the employers' to the employees' part of the wedge. The tax reform that started in the '90's in the Netherlands has given an extra impetus to this trend. The so-called Oort operation assumed that a shift from employers' to employees' contributions would not influence wage costs and employment since the total wedge does not change. In line with Dalton's Law, which states that it does not matter which side of the market is taxed, this is a 'harmless' operation and can indeed be used to simplifying the tax system.

Against this background we analyze Dalton's Law in the context of the labour market and look at the influence of taxes in various wage bargaining models. We argue that only in the market model and in a simple bargaining model, Dalton's Law holds. Further, we show that neither of these models seem realistic for the Netherlands - hence Dalton's Law does not hold for the Netherlands. Nevertheless the Oortreform did not cause an upward shift in the wage rate. This 'anomaly' is simply caused by the difference in the relative change of employers' and employees' contributions and in the magnitude of the shifting elasticities of employers'and employees' taxes and premiums - leading to a violation of Dalton's Law. Would these elasticities be the same, as the Oort-committee implicitly assumed, the Oort operation would have increased the wages. 


\section{References}

Blinder, A.S. (1988), The challenge of high unemployment, AEA Papers and Proceedings: American Economic Review, May, pp. 1-15.

Brandsma, A.S. and N. van der Windt (1983), Wage bargaining and the Philips curve: a macroeconomic view, Applied Economics, 15, pp. 61-71.

Central Planning Bureau (CPB) (1983), Freia: Een macroeconomisch model voor de middellange termijn, 's-Gravenhage.

Compaijen, B. and J. A. Vijlbrief (1994), Benefits and unemployment in an open economy: An Equilibrium Analysis, Applied Economics, 26, pp. 765-774.

Dalton, H. (1936), Principles of Public Finance, 9th ed., Routledge \& Kegan, London.

FKSEC (1992), A macroeconometric model for the Netherlands, Central Planning Bureau (CPB)/Stenfert Kroese.

Graafland, J.J. (1990), Persistent unemployment, wages and hysteresis, Dissertation, Helmond.

Graafland, J.J. (1991), Effecten van marginale belasting- en premiedruk op loonvorming, Research Memorandum No. 78, Centraal Planbureau, the Hague.

Hoel, M. (1990), Efficiency wages and income taxes, Journal of Economics, vol. 51, 1990, no. 1, pp. 8999.

Kam, F.A. de (1996), Tax reform in the Netherlands, 1985-1995, in: C. Kool et al., Essays on Money, Banking and Regulation, Kluwer, Boston, pp. 187-215.

Keller, W.J. (1980), Tax incidence, a general equilibrium approach, Elsevier, North Holland.

Knoester, A. and N. van der Windt (1987), Real wages and taxation in ten OECD countries, Oxford Bulletin of Economics and Statistics, 49, 1, pp. 151-169.

Krapels, F.J. and A. van Ravestein (1987), Gemiddeld en marginaal, de druk van belastingen en premies sinds 1960, Onderzoeksmemorandum Nr. 6, Ministerie van Economische Zaken, Den Haag.

Kuipers, S.K. et. al. (1988), CESAM, het CCSO-jaarmodel van de Nederlandse economie, WoltersNoordhoff.

Lever, M.H.C. (1991), Union wage setting and unemployment in the Netherlands (1965-1987), Applied Economics, 23 (10), pp. 1579-1585.

Lever, M.H.C. (1993), Union wge formation and (un)employment, Dissertation, University of Limburg, Maastricht.

MORKMON I (1984), Een kwartaalmodel voor macro-economische beleidsanalyse, Monetaire Monografieën nr 2, De Nederlandsche Bank, Amsterdam.

MORKMON II (1990), Het DNB-kwartaal model voor Nederland, Monetaire Monografieën nr 11, De Nederlandsche Bank, Amsterdam.

Mulder, C.B. (1990), Langdurige werkloosheid in Nederland, ESB, 7/2/1990, pp. 132-136.

Musgrave, R.A. and P.B. Musgrave (1987), Public finance in Theory and Practice, 4th ed., McGraw Hill.

Stiglitz, J.E. (1988), Economics of the Public Sector, 2nd ed., New York.

Svejnar, J. (1986), Bargaining power, fear of disagreement, and wage settlements: theory and evidence from U.S. industry, Econometrica, 54, 5, September, pp. 1055-1078.

Veen, A.P. van and A. van der Veen (1987), Payroll tax shifting and tax push inflation: evidence for the Netherlands, Research Memorandum RM 87-032, University of Limburg, Maastricht. 